\title{
SPECTROPHOTOMETRIC STUDY OF NICKEL (II) COMPLEXES WITH 2- HYDROXYTHIOLPHENOL AND ITS DERIVATIVES IN THE PRESENCE OF HYDROPHOBIC AMINES
}

\author{
A. Z. Zalov, K.O. Iskenderova, Z.G. Askerova, A.B. Hajiyeva \\ Azerbaijan State Pedagogical University, \\ 68, Uz. Hajibeyov st., Az 1000 Baku \\ e-mail: zalov1966@mail.ru
}

Received 18.09.2021

Accepted 10.12.2021

\begin{abstract}
The complexation reactions of nickel (II) with 2-hydroxythiophenol and its derivatives (2,5dihydroxythiophenol, 2-hydroxy-5-chlorothiophenol, 2-hydroxy-5-bromothiophenol, and 2-hydroxy-5iodothiophenol) in the presence of hydrophobic amines were studied by spectrophotometric methods. Aniline and $N, N$-dimethylaniline were used as hydrophobic amines. It found that mixed-ligand complexes (MLC) are formed in a weakly acidic medium ( $p H$ 2.3-8.0). The maximum in the light absorption spectrum of the complexes is observed at $\lambda=620-650 \mathrm{~nm}$. The molar coefficients of light absorption are (4.1-4.3) $\times 10^{4}$. The best extractants were chloroform, dichloroethane and carbon tetrachloride. With a single extraction with chloroform, 97.8-98.4\% of nickel is extracted in the form of MLC. Based on the data obtained, photometric methods for the determination of nickel in various objects were developed.
\end{abstract}

Keywords: nickel, 2-hydroxythiophenol, 2,5-dihydroxythiophenol, 2-hydroxy-5-chlorothiophenol, 2-hydroxy5-bromothiophenol, 2-hydroxy-5-iodothiophenol, aniline.

DOI: 10.32737/2221-8688-2021-4-224-231

\section{Introduction}

Many chelating reagents belonging to different classes of compounds and containing $\mathrm{N}, \mathrm{O}$, or $\mathrm{S}$ as donor atoms are suitable for the photometric determination of nickel [1]. It is known that by improving the analytical parameters of the reaction of mixed-ligand complexes (MLC) formation, they have found wide application in the photometric determination of elements [2-5].

According to the hypothesis of analogies, reactions with reagents of the $\mathrm{R}-\mathrm{SH}$ type are possible for ions of elements that form sulfides which are poorly soluble in water [6]. It was of interest to study the interaction of nickel with 2-hydroxythiophenol (HTP) and its derivatives \{2,5-dihydroxythiophenol (DHTP), 2-hydroxy-5-chlorothiophenol (HCTP), 2hydroxy-5-bromothiophenol (HBTF) and 2hydroxy -5-iodothiophenol (HITP) $\}$ and hydrophobic amines (Am) \{aniline (An) and N, $\mathrm{N}$-dimethylaniline (dAn) $\}$.

\section{Experimental part}

Reagents and solutions. A solution of nickel (II) (0.1 mg / ml) was prepared by dissolving in water $\mathrm{NiCl}_{2} \times 6 \mathrm{H}_{2} \mathrm{O}$. The titer of the solution was established by the gravimetric method in the form of dimethylglyoxime [2]. Solutions with a concentration of $0.1 \mathrm{mg} / \mathrm{ml}$ were obtained by diluting the stock solution.

Hydroxythiophenol derivatives (L) were purified by reprecipitation from ethanol solutions by adding water and then by distillation. We used $0.01 \mathrm{M}$ solutions of $\mathrm{L}$ chloroform. Purified chloroform was used as an extractant.The ionic strength of solutions equal to $\mu=0.1$ was maintained constant by introducing a calculated amount of $\mathrm{KCl}$. To create the required acidity of the solutions, a $1 \mathrm{M}$ 
$\mathrm{NaOH}$ solution was used. All reagents used were of analytical grade. or $\mathrm{x} . \mathrm{h}$.

Apparatus. The optical density of the organic phase was measured on KFK-2 and SF26. The $\mathrm{pH}$ value of the aqueous phase was monitored using an I-120.2 instrument with a glass electrode. The NMR spectra of the reagents were recorded on a Bruker pulse Fourier spectrometer (Germany), at an operating frequency of $300.18 \mathrm{MHz}$, in deuterated benzene at room temperature. The relative abundance of protons of various structural groups was determined by integrating the corresponding resonance absorption bands.
IR spectra were recorded on a Bruker spectrophotometer.

Methods. Graduated tubes with groundin stoppers were injected with $0.1-0.8 \mathrm{ml}$, with an interval of $0.1 \mathrm{ml}$ of the initial nickel solution, $2.5 \mathrm{ml}$ of a $0.01 \mathrm{M}$ solution of $\mathrm{L}$, and $0.8-1.0 \mathrm{ml}$ of $\mathrm{Am}$. The required $\mathrm{pH}$ value was set by adding $1 \mathrm{M} \mathrm{NaOH}$ solution. The volume of the organic phase was brought to $5 \mathrm{ml}$ with chloroform, and the volume of the aqueous phase - to $20 \mathrm{ml}$ with distilled water. After 5 minutes, the organic layer was separated and its optical density was measured at room temperature on KFK-2 at $490 \mathrm{~nm}$.

\section{Results and discussion}

$\mathrm{L}$ are dibasic (HTP, HCTP, HBTF and HITF, $\mathrm{H}_{2} \mathrm{~L}$ ) and tribasic weak acid (DHTP, $\mathrm{H}_{3} \mathrm{~L}$ ) and, depending on the $\mathrm{pH}$ of the medium, can exist in molecular and anionic forms. Their estimates of the ionization constants obtained by potentiometric titration are as follows: DHTP $\left(\mathrm{pK}_{1}=6.33 ; \mathrm{pK}_{2}=8.82 ; \mathrm{pK}_{3}=12.78\right), \mathrm{HTP}$ DHTP: $\mathrm{pK}_{1}=6.88-0.77 \sqrt{ } \mu ; \mathrm{pK}_{1}=9.76-0.77 \sqrt{ } \mu$; HTP: $\quad \mathrm{pK}_{1}=5.65-0.53 \sqrt{\mu} ; \quad \mathrm{pK}_{2}=11.21-0.35 \sqrt{ } \mu$. HCTP: $\mathrm{pK}_{1}=5.28-0.56 \sqrt{\mu} ; \mathrm{pK}_{2}=10.73-0.40 \sqrt{ } \mu$. HBTF: $\quad \mathrm{pK}_{1}=5.26-0.67 \sqrt{\mu} ; \quad \mathrm{pK}_{2}=10.53-0.42 \sqrt{\mu}$. HITF: $\quad \mathrm{pK}_{1}=5.15-0.46 \sqrt{\mu} ; \mathrm{pK}_{2}=10.36-0.51 \sqrt{ } \mu$.

The synthesized compounds were and NMR spectroscopy (Table 1) [7,8]: determined by physicochemical methods: IR

Table 1. Results of IR and NMR spectroscopy studies

\begin{tabular}{|l|l|l|}
\hline Reagents & IR spectrum $\left(\mathrm{KBr}, \mathrm{v}, \mathrm{cm}^{-1}\right):$ & Spectrum ${ }^{1} \mathrm{H} \mathrm{NMR}\left(300,18 \mathrm{MHz}, \mathrm{C}_{6} \mathrm{D}_{6}, \delta, \mathrm{ppm}\right):$ \\
\hline HTP & $3470(\mathrm{OH}), 2580(\mathrm{SH}), 1580\left(\mathrm{C}_{6} \mathrm{H}_{5}\right)$ & $\begin{array}{l}5.48(\mathrm{~s}, 1 \mathrm{H}, \mathrm{OH}), 3.47(\mathrm{~s}, 1 \mathrm{H}, \mathrm{SH}), 7.28(\mathrm{~s}, 2 \mathrm{H}, \\
\mathrm{Ar}-\mathrm{H}), 6.95(\mathrm{~s}, 1 \mathrm{H}, \mathrm{Ar}-\mathrm{H}), 6.92(\mathrm{~s}, 1 \mathrm{H}, \mathrm{Ar}-\mathrm{H}) .\end{array}$ \\
\hline DHTP & $3460(\mathrm{OH}), 2570(\mathrm{SH}), 1555\left(\mathrm{C}_{6} \mathrm{H}_{5}\right)$ & $\begin{array}{l}5.24(\mathrm{~s}, 2 \mathrm{H}, \mathrm{OH}), 3.38(\mathrm{~s}, 1 \mathrm{H}, \mathrm{SH}), 7.11(\mathrm{~s}, 2 \mathrm{H}, \\
\mathrm{Ar}-\mathrm{H}), 6.95(\mathrm{~s}, 1 \mathrm{H}, \mathrm{Ar}-\mathrm{H}) .) .\end{array}$ \\
\hline HCTP & $3458(\mathrm{OH}), 2568(\mathrm{SH}), 1535\left(\mathrm{C}_{6} \mathrm{H}_{5}\right)$ & $\begin{array}{l}5.70(\mathrm{~s}, 1 \mathrm{H}, \mathrm{OH}), 3.35(\mathrm{~s}, 1 \mathrm{H}, \mathrm{SH}), 7.05(\mathrm{~s}, 2 \mathrm{H}, \\
\mathrm{Ar}-\mathrm{H}), 6.42(\mathrm{~s}, 1 \mathrm{H}, \mathrm{Ar}-\mathrm{H}) .\end{array}$ \\
\hline HBTP & $3462(\mathrm{OH}), 2563(\mathrm{SH}), 1532\left(\mathrm{C}_{6} \mathrm{H}_{5}\right)$ & $\begin{array}{l}5.72(\mathrm{~s}, 1 \mathrm{H}, \mathrm{OH}), 3.31(\mathrm{~s}, 1 \mathrm{H}, \mathrm{SH}), 7.09(\mathrm{~s}, 2 \mathrm{H}, \\
\mathrm{Ar}-\mathrm{H}), 6.38(\mathrm{~s}, 1 \mathrm{H}, \mathrm{Ar}-\mathrm{H}) .\end{array}$ \\
\hline HITP & $3460(\mathrm{OH}), 2571(\mathrm{SH}), 1539\left(\mathrm{C}_{6} \mathrm{H}_{5}\right)$ & $\begin{array}{l}5.69(\mathrm{~s}, 1 \mathrm{H}, \mathrm{OH}), 3.28(\mathrm{~s}, 1 \mathrm{H}, \mathrm{SH}), 7.12(\mathrm{~s}, 2 \mathrm{H}, \\
\mathrm{Ar}-\mathrm{H}), 6.34(\mathrm{~s}, 1 \mathrm{H}, \mathrm{Ar}-\mathrm{H}) .\end{array}$ \\
\hline
\end{tabular}

Influence of pH of the aqueous phase. The study into the dependence of complexation on $\mathrm{pH}$ showed that the optimal range of acidity, at which the optical density is maximum and
$\left(\mathrm{pK}_{1}=5.8 ; \mathrm{pK}_{2}=10.9\right), \operatorname{HCTP}\left(\mathrm{pK}_{1}=5.1 ; \mathrm{pK}_{2}\right.$ $=10.6)$, HBTF $\left(\mathrm{pK}_{1}=5.05 ; \mathrm{pK}_{2}=10.4\right), \mathrm{HITF}$ $\left(\mathrm{pK}_{1}=5.0 ; \mathrm{pK}_{2}=10.2\right)$. The dependence of the ionization constant $(\mathrm{pKa})$ for $\mathrm{L}$ on the ionic strength of the solution in the range $\mu=0-1$ is linear and corresponds to the following equation:

$$
\mathrm{pK}_{2}=11.73-0.63 \sqrt{ } \mu
$$


the other hand, in the case of DHTP, the concentration of the non-extractable complex $\left[\mathrm{NiL}_{2}\right]^{4-}$ in an aqueous solution increases, since the dissociation at the second $-\mathrm{OH}$ group continues to increase. The dependence of optical density on $\mathrm{pH}$ is shown in Fig. 1. The presence of one maximum of optical density within the indicated $\mathrm{pH}$ range confirms the assumption of the formation of one complex compound.

Absorption spectra. The maximum analytical signal during the complexation of nickel with $\mathrm{L}$ and Am is observed at 520-550 $\mathrm{nm}$ (Fig. 1). L absorb maximum at $278-283 \mathrm{~nm}$.
During complexation, a bathochromic shift of the absorption maximum by $239-267 \mathrm{~nm}$ is observed. The contrast of the reactions is high: the initial reagents are almost colorless, and the complexes are red. Colored chloroform extracts of hydroxythiophenolate-amine associates absorb maximum at $325-335 \mathrm{~nm}$. A sharp difference in the values of the maximums of light absorption of complexes and associates allows us to conclude that the resulting compounds are MLCs with a mixed coordination sphere. The molar absorption coefficients are $(4.1-4.3) \times 10^{4}$.

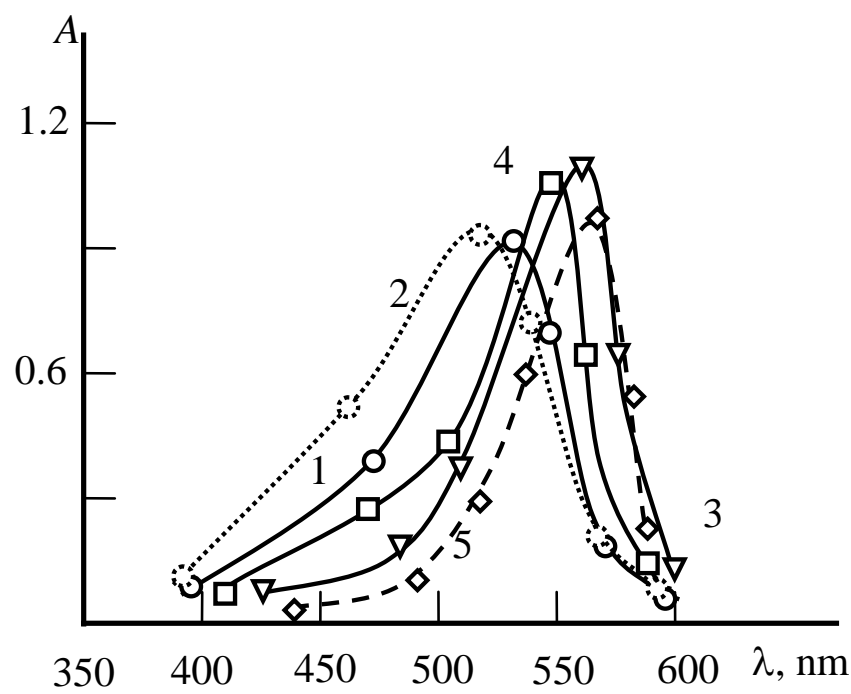

Fig. 1. Absorption spectra of nickel complexes with $\mathrm{L}$ and An.

1. Ni-HTP-An; 2. Ni-DHTP-An; 3. Ni-HCTP-An; 4. Ni-HBTP-An; 5. Ni-HITP-An $\mathrm{C}_{\mathrm{Ni}}=3.4 \times 10^{-5} \mathrm{M} ; \mathrm{C}_{\mathrm{L}}=(0.8-1.0) \times 10^{-3} \mathrm{M} ; \mathrm{C}_{\mathrm{AH}}=(1.0-1.2) \times 10^{-3} \mathrm{M}, \mathrm{SP}-26, \lambda=590 \mathrm{~nm}, \ell=1.0 \mathrm{~cm}$

The choice of the extractant. Nonaqueous solvents were used for MLC extraction: chloroform, 1,2-dichloroethane, carbon tetrachloride, benzene, chlorobenzene, toluene, xylol, isobutanol, and isopentanol. The best extractants were chloroform, dichloroethane and carbon tetrachloride. With a single extraction with chloroform, 97.8-98.4\% of nickel is extracted in the form of MLC. Further studies were carried out with chloroform. The copper content in the organic phase was determined photometrically - with dimethylglyoxime after re-extraction [2], and in the water phase - by the difference.

Influence of ligand concentration and holding time. Nickel MLCs are formed in the presence of a large excess of complexing reagents. The optimal condition for the formation and extraction of these compounds is (0.8-1.0) $\times 10^{-3} \mathrm{M}$ concentration of $\mathrm{L}$ and (1.0$1.2) \times 10^{-3} \mathrm{M}-\mathrm{Am}$.

MLC of nickel with $\mathrm{L}$ and Am are stable in aqueous and organic solvents and do not decompose within three days, and after extraction - more than a month. The maximum optical density is reached within 5 minutes.

Composition and structure of the complexes. The stoichiometry of the complexes under study was established by the methods of equilibrium shift and relative yield [9]. In the 
composition of the MLC, there are two moles of $\mathrm{L}$ and Am per mole of metal. Using the Nazarenko method, it was established that the complexing form of nickel is $\mathrm{Ni}^{2+}$ [10]. In this case, the number of protons displaced by it from one molecule L turned out to be equal to 2 (Fig. 2).

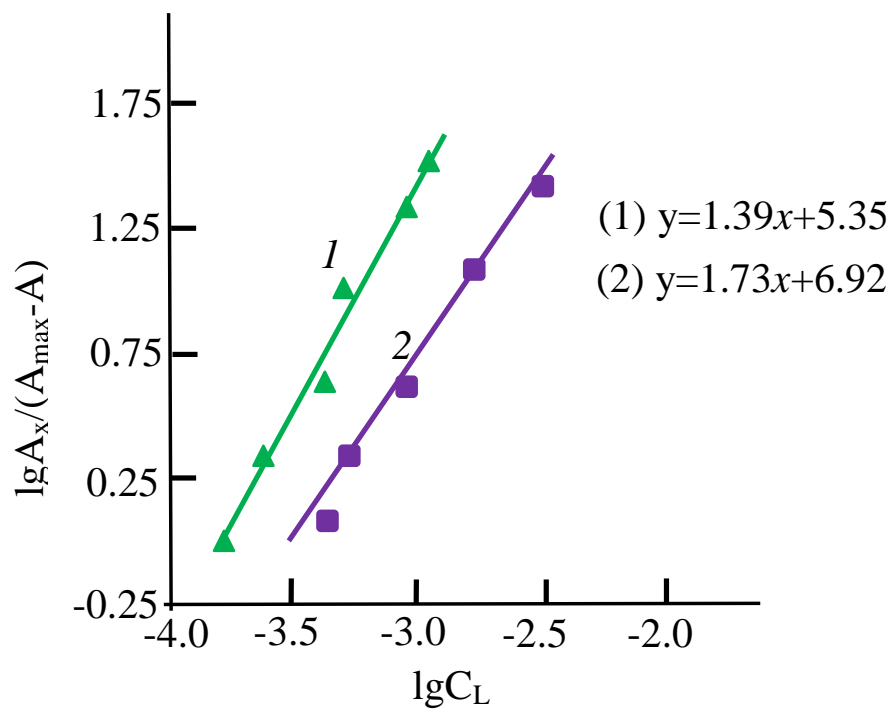

Fig.2. Determination of the HITP-to-Ni (straight line 1) and the An-to-Ni (straight line 2) molar ratios by the mobile equilibrium method. $\mathrm{C}_{\mathrm{Ni}}=3.4 \times 10^{-5} \mathrm{M}, \mathrm{C}_{\mathrm{L}}=1.2 \times 10^{-3} \mathrm{M}, \mathrm{C}_{\mathrm{An}}=2.0 \times 10^{-3} \mathrm{M}$, $\lambda=550 \mathrm{~nm}, \mathrm{KFK}-2, \ell=0.5 \mathrm{~cm}$.

An intense absorption band appears in the IR spectra of the Ni-HTP-An complex in the region of 950-960 cm-1, which is absent in the spectra of the reagent. This band is due to the stretching vibration of the metal-ligand bond. The disappearance of a pronounced band at $2580 \mathrm{~cm}^{-1}$, observed in the HTP spectrum, suggests that the $-\mathrm{SH}$ groups are involved in the formation of the complex. The observed decrease in the intensity of the absorption band in the region of $3200-3600 \mathrm{~cm}^{-1}$ with a maximum at $3460 \mathrm{~cm}^{-1}$ and the appearance of a wide band in the region of $3050-3160 \mathrm{~cm}^{-1}$ reveals that the $-\mathrm{OH}$ group is involved in the formation of coordination bonds in an ionized state. The detection of absorption bands at 1370 $\mathrm{cm}^{-1}$ indicates the presence of protonated aniline $[7,8]$.

The calculations showed that MLC in the organic phase does not polymerize and is in the monomeric form $(\gamma=0.94-1.07)$ [11].

Table 2 shows the main spectrophotometric characteristics of MLC nickel.

Table 2. Characteristics of MLC nickel with L and Am

\begin{tabular}{|c|c|c|c|c|c|c|c|c|}
\hline \multirow[t]{2}{*}{ Соединение } & \multicolumn{2}{|c|}{$\mathrm{pH}$} & \multirow[b]{2}{*}{$\begin{array}{r}\lambda, \\
\mathrm{nm}\end{array}$} & \multirow[b]{2}{*}{$\varepsilon \times 10^{-4}$} & \multirow[b]{2}{*}{$\operatorname{lgk}_{\text {eq. }}$} & \multirow[b]{2}{*}{$1 g k_{e x}$} & \multirow[b]{2}{*}{$\lg \beta_{\mathrm{k}}$} & \multirow[b]{2}{*}{$\begin{array}{c}\text { Working range } \\
\mu \mathrm{g} / \mathrm{ml}\end{array}$} \\
\hline & $\begin{array}{l}\text { Education } \\
\text { and } \\
\text { extraction }\end{array}$ & Opt. & & & & & & \\
\hline$\left[\mathrm{Ni}(\mathrm{DHTP})_{2}\right](\mathrm{AnH})_{2}$ & $3.4-8.0$ & $3.8-6.5$ & 620 & 4.3 & 3.69 & 9.69 & 10.67 & $0.2-20$ \\
\hline$\left[\mathrm{Ni}(\mathrm{HTP})_{2}\right](\mathrm{AnH})_{2}$ & $3.0-7.5$ & $3.5-6.0$ & 630 & 4.2 & 3.49 & 9.26 & 10.28 & $0.2-20$ \\
\hline$\left[\mathrm{Ni}(\mathrm{HCTP})_{2}\right](\mathrm{AnH})_{2}$ & $2.3-6.5$ & $2.6-5.3$ & 650 & 4.0 & 3.51 & 9.31 & 9.75 & $0.2-13$ \\
\hline$\left[\mathrm{Ni}(\mathrm{HCTP})_{2}\right](\mathrm{DAnH})_{2}$ & $2.4-6.6$ & $2.7-5.4$ & 648 & 4.1 & 3.57 & 9.55 & 9.77 & $0.2-15$ \\
\hline$\left[\mathrm{Ni}(\mathrm{HBTP})_{2}\right](\mathrm{AnH})_{2}$ & $1.9-6.2$ & $2.4-4.8$ & 655 & 3.8 & 3.43 & 9.71 & 9.45 & $0.2-15$ \\
\hline$\left[\mathrm{Ni}(\mathrm{HITP})_{2}\right](\mathrm{AnH})_{2}$ & $1.5-5.5$ & $2.1-4.3$ & 660 & 3.6 & 3.82 & 10.26 & 9.08 & $0.2-12$ \\
\hline
\end{tabular}

Based on the data obtained, the represented by the formula $\left.\left[\mathrm{NiL}_{2}\right)\right](\mathrm{AmH})_{2}$. The composition of the extracted complexes can be mechanism of MLC formation can be 
represented as follows: $\mathrm{L}$ at $\mathrm{pH}$ 1.5-8.0 forms a compound insoluble in chloroform with an excess of nickel ions. Am is added to such a system, an intensely colored compound, soluble in chloroform, is instantly given.

$$
\begin{gathered}
\mathrm{Ni}^{2+}+2 \mathrm{H}_{2} \mathrm{~L} \leftrightarrow\left[\mathrm{NiL}_{2}\right]^{2-}+4 \mathrm{H}^{+} \\
{\left[\mathrm{NiL}_{2}\right]^{2-}+2 \mathrm{AmH}^{+} \leftrightarrow\left[\mathrm{NiL}_{2}\right](\mathrm{AmH})_{2}} \\
\begin{array}{c}
\text { The equilibrium constant of the reaction is } \\
\left\{\left[\mathrm{NiL}_{2}(\mathrm{AmH})_{2}\right)_{\mathrm{orq}}\right.
\end{array}=\lg \frac{\mathrm{A}_{\mathrm{x}}}{\mathrm{A}_{\mathrm{p}}-\mathrm{A}_{\mathrm{x}}}=\mathrm{D} \\
\left\{\left[\mathrm{NiL}_{2}\right]^{2-}\right\}_{\mathrm{aq}}\left\{[\mathrm{AmH}]^{+}\right\}_{\mathrm{aq}} \\
\mathrm{K}_{\mathrm{p}}=\frac{\mathrm{D}}{[\mathrm{AmH}]^{2}}
\end{gathered}
$$

Taking the logarithm of the last expression, we get

$$
\lg \mathrm{K}_{\mathrm{eq}}=\lg \mathrm{D}-2 \lg \left[\mathrm{AmH}^{+}\right]
$$

The extraction constants were calculated using the equations

$$
\lg \mathrm{K}_{\mathrm{ex}}=\lg \mathrm{D}-2 \lg \left[\mathrm{H}_{2} \mathrm{~L}\right]-2 \lg \left[\mathrm{AmH}^{+}\right] \text {. }
$$

The results of calculating the equilibrium quantitative determination limit of nickel in the constant and the extraction of the reaction were form of MLC were calculated [12]. Table 3 shown in Table. 2.

Based on the equations of the calibration curves, the photometric detection limit and the

Table 3. Analytical characteristics of MLC nickel with L and An

\begin{tabular}{|l|c|c|c|}
\hline \multicolumn{1}{|c|}{ Parameter } & Ni-DHTP-An & Ni-HTP-An & Ni-HCTP-An \\
\hline $\begin{array}{l}\text { Equation of calibration } \\
\text { curves }\end{array}$ & $y=0.086+0.0066 \mathrm{x}$ & $y=0.062+0.0073 \mathrm{x}$ & $y=0.093+0.0070 \mathrm{x}$ \\
\hline Correlation coefficient & 0.9981 & 0.9984 & 0.9989 \\
\hline $\begin{array}{l}\text { Linear range of calibration } \\
\text { curves, } \mu \mathrm{g} / \mathrm{ml}\end{array}$ & $0.06-3.2$ & $0.04-3.5$ & $0.04-3.6$ \\
\hline Detection limit ng/cm & & 8.70 & 8.50 \\
\hline $\begin{array}{l}\text { Limit of quantitative } \\
\text { determination, } \mathrm{ng} / \mathrm{cm}^{3}\end{array}$ & 28.0 & 26.5 & 23.4 \\
\hline Sensitivity, $\mathrm{ng} / \mathrm{cm}^{2}$ & 2.41 & 2.31 & 2.19 \\
\hline
\end{tabular}

The dependences we found agree with the literature data, indicating that with an increase in $\mathrm{pK}_{1}$ of complexing reagents, the strength of the complex compounds formed by them and the $\mathrm{pH}$ of complexation increase as well.

The influence of foreign ions. To assess the applicability of RLC for the separation and determination of nickel, the interfering effect of foreign ions was studied. It was found that large amounts of alkaline, alkaline-earth elements, REE, F-, CI-, do not interfere with the determination of nickel. Citrates and tartrates, $\mathrm{J}^{-}$, $\mathrm{CN}^{-}, \mathrm{S}_{2} \mathrm{O}_{3}{ }^{2-}$, thiourea interfere with the determination. The interfering influence of $\mathrm{Fe}$ (III) was eliminated with oxalic acid; Ti (IV) sodium fluoride or Tyron; $\mathrm{Hg}$ (II) sulfite ion; $\mathrm{Nb}(\mathrm{V})$ and $\mathrm{Ta}(\mathrm{V})$ - with oxalic acid, and Mo (VI) and W (VI) - with sodium fluoride and oxalic acid. When using a $1 \%$ solution of 
ascorbic acid, the determination does not interfere with $\mathrm{Mn}$ (VII), V (IV), Nb (V), Cr (VI), Mo (VI) and Fe (III). When using a $0.01 \mathrm{M}$ solution of oxalic acid, V (IV), Nb (V), Ta (V), Cr (III), Mo (VI), W (VI) and Fe (III) do not interfere with the determination.
The comparison of methods for the determination of $\mathrm{Ni}$ (II) with known reagents and $\mathbf{L}$ in the presence of amines. Table 4 shows the data allowing to compare the analytical characteristics of the photometric methods developed by us for the determination of $\mathrm{Ni}$ (II) with some already known methods.

Table 4. Comparative characteristics of methods for determination of nickel (II)

\begin{tabular}{|l|l|l|l|c|}
\hline \multicolumn{1}{|c|}{ Reagent } & $\mathrm{pH}$ & $\lambda_{\text {мах }}$ & $\mathcal{E}$ & $\begin{array}{l}\text { Working } \\
\text { range } \\
\mu \mathrm{g} / \mathrm{ml}\end{array}$ \\
\hline Dimethylglyoxime [1] & 12 & 470 & - & $0.26-2.1$ \\
\hline N-ethyl-3-carbazolecarboxaldehyde-3-thiosemicarbazone [13] & 6.0 & 400 & 1.11 & - \\
\hline 7-Methyl-2-chloroquinoline-3-carbaldehyde-thiosemicarbazone [14] & 6.0 & 410 & $1.67 \times 10^{2}$ & - \\
\hline Thiazole-2-carbaldehyde-2-quinolylhydrazone [15] & $8.7-9.5$ & 522 & $7.17 \times 10^{4}$ & 0.7 \\
\hline Pyridoxal-4-phenyl-3-thiosemicarbazone [16] & $4-6$ & 430 & 1.92 & $0.5-5$ \\
\hline 4-Hydroxybenzaldehyde-4-bromophenylhydrazine [17] & 4 & 497 & 12.85 & $0.01-0.1$ \\
\hline DHTP-An & $3.8-6.5$ & 620 & $4.3 \times 10^{4}$ & $0.2-20$ \\
\hline HTP-An & $3.5-6.0$ & 630 & $4.2 \times 10^{4}$ & $0.2-20$ \\
\hline HCTP-An & $2.6-5.3$ & 650 & $4.1 \times 10^{4}$ & $0.2-13$ \\
\hline HBTP-An & $2.4-4.8$ & 655 & $3.8 \times 10^{4}$ & $0.2-15$ \\
\hline HITP-An & $2.1-4.3$ & 660 & $3.6 \times 10^{4}$ & $0.2-12$ \\
\hline
\end{tabular}

The results of studies of the formation and extraction of Ni (II) MLCs with L and Am, the physicochemical and analytical characteristics of these compounds served as the basis for the development of new methods for the extraction-photometric determination of $\mathrm{Ni}$ (II) in magnesium and carnallite.

\section{Determination of nickel in magnesium}

and carnallite. The developed analytical procedure was applied for the analysis of real samples. Four replicates of metallic magnesium and four samples of carnallite were subjected to the analysis. The results are shown in Table 5; their reliability was verified by the addedrecovered method.

Table 5. Determination of nickel in metallic magnesium and carnallite

\begin{tabular}{|l|c|c|c|c|}
\hline \multirow{3}{*}{ Sample } & Found $(\%) \times 10^{-4}$ & \multicolumn{3}{|c|}{ Added-recovered method } \\
\cline { 2 - 5 } & \multirow{2}{*}{$\mathrm{Ni}$} & Added $(\%) \times 10^{-3}$ & Recovered $(\%) \times 10^{-3}$ & RSD (\%) \\
\cline { 2 - 5 } & & $\mathrm{Ni}$ & $\mathrm{Ni}$ & $\mathrm{Ni}$ \\
\hline $1^{\mathrm{a}}$ & $7.65 \pm 0.01$ & 1 & 1.765 & 1.4 \\
\hline $2^{\mathrm{a}}$ & $7.64 \pm 0.02$ & 1 & 1.764 & 1.5 \\
\hline $3^{\mathrm{a}}$ & $7.70 \pm 0.02$ & 1 & 1.763 & 1.3 \\
\hline $4^{\mathrm{a}}$ & $7.63 \pm 0.02$ & 1 & 1.871 & 1.3 \\
\hline $1^{\mathrm{b}}$ & $8.71 \pm 0.01$ & 1 & 1.869 & 1.8 \\
\hline $2^{\mathrm{b}}$ & $8.69 \pm 0.02$ & 1 & 1.890 & 1.2 \\
\hline $3^{\mathrm{b}}$ & $8.90 \pm 0.01$ & 1 & 1.881 & 1.5 \\
\hline $4^{\mathrm{b}}$ & $8.81 \pm 0.01$ & 1 & & \\
\hline
\end{tabular}

Note: ${ }^{\mathrm{a}}$ - Metallic magnesium; $n=6 ; \mathrm{P}=95 \% ;{ }^{\mathrm{b}}-$ Carnallite; $n=5 ; \mathrm{P}=95 \%$ 


\section{References}

1. Umland F., Iansen A., Tirig D., Viunsh G. Complex connections in analytical chemistry. Theory and practice of application. Moscow: Mir Publ., 1975. 531 p.

2. Marczenko Z., Baltsejak M.K. Spectrophotometrically in the UV and visible regions in inorganic analysis. Moscow: Binom. Laboratoriya znaniy. 2007, 711 p.

3. Pilipenko A.T., Tananaiko M.M. Differentligand and different-metal complexes and their application in analytical chemistry. Moscow: Chemistry Publ., 1983.221 p.

4. Zalov A.Z., Verdizade N.A. Extraction spectrophotometry determination of tungsten with 2-hydroxy-5-chlorothiophenol and hydrophobic amines. Journal of Analytical Chemistry.2013, vol. 68, p. 212. (In Russian).

5. Zalov A.Z., Isgenderova K.O., Askerova Z.G. Spectrophotometric research into interaction nickel (II) with 1- (2-pyridylazo) -2- hydroxy -4-mercaptofenol and aminophenols. Chemical Problems 2021, no. 3 (19), pp. 150-159.

6. Haji-Shabani A.M., Dadfarnia S., Shahbaazi Z., Jafari A.A. Extraction-spectrophotometric determination of nickel at microgram level in water and wastewater using 2-[(2mercaptophenylimino)methyl]phenol. Bull. Chem. Soc. Ethiop. 2008, vol. 22, no. 3, pp. 323-329.

7. Ioffe B.V., Kostikov R.R., Razin V.V. Physical methods for determining the structure of organic compounds. M.: Visshaya shkola Publ. 1984. 336 s. (In Russian).

8. Anisimova N.A. Identification of organic compounds. Gorno-Altaysk, 2009. 118 p.

9. Bulatov M.I., Kalinkin I.P. Practicheskoe rukovodstvo po photocolorimetricheskim $i$ spectrophotometricheskim metodam analysa - A practical guide to photocolorimetric and spectrophotometric methods of analysis. Leningrad, 1986, p. 432. (In Russian).

10. Nazarenko V.A., Biryuk E.A. A study of the chemistry of reactions of multivalent element ions with organic reagents. Zh. Anal. Khim., 1967, vol. 22, no. 13, pp. 57-64. (In Russian).

11. Akhmedli M.K., Klygin A.E., Ivanova L.I., Bashirov E.A. On the chemistry of the interaction of gallium ions with some sulfophthalenes. Zh. inorgan. chemistry. 1974, vol. 19, no.8, pp. 2007-2012.

12. Dorokhova E.N., Prokhorova G.V. Analytical chemistry (physicochemical methods of analysis). Moscow: Visshaya shkola Publ. 1991, p. 250. (In Russian).

13. Ramachandraiah C., Kumar J.R., Reddy K.J. Development of a highly sensitive extractive spectrophotometric method for the determination of nickel(II) from environmental matrices using N-ethyl-3carbazolecarboxaldehyde-3-

thiosemicarbazone. J. Environ Manage. 2008, vol. 88, no 4, pp. 729-736.

14. Jadhav V.A., Kulkarni M.U. 7-Methil-2chloroquinoline-3-carbaldehyde

thiosemicarbazone as analytical reagent for copper, cobalt and nickel (II). J. Indian Chem. Soc. 1992, vol. 69, pp. 287-288.

15. Otomo M., Watanabe T., Moriya M. Solvent Extraction and Spectrophotometric De ter mi na tion of Nickel (II) with Thiazole-2carbaldehyde 2-Quinolyl- hydrazone. Analyt. Sci. 1986, vol. 2, no. 6, pp. 549-552.

16. Sarma L.S., Kumar J.R., Reddy K.J. Development of highly sensitive extractive spectro photometric determination of nickel(II) in medicinal leaves, soil, industrial effluents and standard alloy samples using pyridoxal-4-phenyl-3-thiosemicarbazone. $J$. of Trace Elements in Med. and Biol. 2008, vol. 22, pp. 285-295.

17. Rekha D., Kumar J. D., Jayaraj B. Nickel(II) Determination by Spectrophotometry Coupled with Preconcentration Technique in Water and Alloy Samples. Bull. Korean Chem. Soc. 2007, vol. 28, no. 3, pp. 373378. 


\title{
NIKELIN (II) 2-HIDROKSITIOLFENOL, ONUN TÖRӘMOLORI VӘ HIDDROFOB AMINLORLO KOMPLEKSLORININ SPEKTROFOTOMETRIK TODQIQI
}

\author{
O.Z. Zalov, K.O. İsgandorova, Z.Q. Osgarova, A.B. Hacıyeva \\ Azarbaycan Dövlat Pedaqoji Universiteti, \\ Az 1000 Bakı, Uz. Hacıbəyov, küç., 68 \\ e-mail:zalov1966@mail.ru
}

Nikelin (II) hidrofob amin iştirakında 2-hidroksitiofenol va onun töramolorila (2,5-dihidroksitiofenol, 2-hidroksi-5-xlorotiofenol, 2-hidroksi-5-bromotiofenol va 2-hidroksi-5-yodtiofenol) komplekslari spektrofotometrik üsulla tadqiq edilmişdir. Hidrofob amin kimi anilin va N, N-dimetilanilin istifadə edilmişdir. Müəyyən edilmişdir ki, müxtalifliqandlı komplekslər (MLK) zəif turşu mühitdo ( $\mathrm{pH}$ 2.3-8.0) amala galir. Komplekslarin işıq udma spektrinda maksimum $\lambda=620-650 \mathrm{~nm}-\mathrm{da}$ müşahido olunur. Molyar işıqudma omsalı (4.1-4.3) × $10^{4}$-dür. Әn yaxşı ekstragent kimi xloroform, dixloretan va karbontetraxlorid seçilmişdir. Xloroform ila birdəfaya 97.8-98.4\% nikel MLC şəklində ekstraksiya olunur. Alınan malumatlar asasında müxtəlif obyektlardə nikelin təyini üçün fotometrik üsullar işlanib hazırlanmışdır.

Açar sözlor: nikel, 2-hidroksitiofenol, 2,5-dihidroksitiofenol, 2-hidroksi-5-xlorotiofenol, 2-hidroksi5-bromotiofenol, 2-hidroksi-5-iyodotiofenol, anilin.

\section{СПЕКТРОФОТОМЕТРИЧЕСКОЕ ИЗУЧЕНИЕ КОМПЛЕКСОВ НИКЕЛЯ (II) С 2-ГИДРОКСИТИОЛФЕНОЛОМ И ЕГО ПРОИЗВОДНЫМИ В ПРИСУТСТВИИ ГИДРОФОБНЫХ АМИНОВ}

\author{
А.З. Залов, К.О. Искандерова, З.Г. Аскерова, А.Б. Гаджиева \\ Азербайджанский Государственный Педагогический Университет, \\ Аз 1000 Баку, ул. Уз. Гаджибекова, 68 \\ e-mail:zalov1966@mail.ru
}

Реакичи комплексообразования никеля (II) с 2-гидрокситиофенолом и его производными (2,5дигидрокситиофенол, 2-гидрокси-5-хлортиофенол, 2-гидрокси-5-бромтиофенол и 2гидрокси-5-йодотиофенол) в присутствии гидрофобных аминов исследовали спектрофотометрическим методом. В качестве гидрофобных аминов использовали анилин $u$, $N$ диметиланилин. Установлено, что разнолигандные комплексы (РЛК) образуются в слабокислой среде ( $\mathrm{pH}$ 2.3-8.0). Максимум в спектре поглощения света комплексов наблюдается при $\lambda=620-650$ нм. Молярные коэффициенты поглощения света составляют

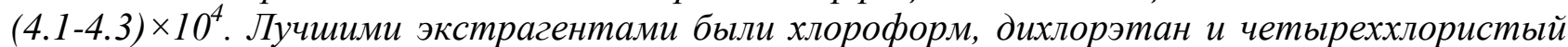
углерод. При однократной экстракции хлороформом 97.8-98.4\% никеля извлекается в виде РЛК. На основе полученных данных разработаны фотометрические методы определения никеля в различных объектах.

Ключевые слова: никель, 2-гидрокситиофенол, 2,5-дигидрокситиофенол, 2-гидрокси-5хлортиофенол, 2-гидрокси-5-бромтиофенол, 2-гидрокси-5-йодотиофенол, анилин. 